DOI: https://doi.org/10.47405/mjssh.v5i10.496

\begin{tabular}{|c|c|}
\hline 4 & Malaysian Journal of Social Sciences and Humanities (MJSSH) \\
\hline $\begin{array}{l}\text { Malaysian Journal of } \\
\text { Social sciences and }\end{array}$ & Volume 5, Issue 10, October 2020 \\
\hline (MJ-SSH) & e-ISSN : 2504-8562 \\
\hline & $\begin{array}{l}\text { Journal home page: } \\
\text { www.msocialsciences.com }\end{array}$ \\
\hline
\end{tabular}

\title{
Pilihanraya Kecil Kimanis: Isu Lokal, Jentera Kempen dan Aura Barisan Nasional
}

\author{
Syahruddin Ag. Ahmad1, Saat Ag. Damit', Haryati Karim¹ \\ 1Universiti Malaysia Sabah (UMS) \\ Correspondence: Syahruddin Ag. Ahmad (syahag@ums.edu.my)
}

\begin{abstract}
Abstrak
Penolakan Mahkamah Pilihan Raya terhadap rayuan oleh penyandang kerusi P176 bagi petisyen untuk mencabar kemenangan penyandang berkenaan telah menyebabkan Pilihanraya Kecil (PRK) diadakan di kawasan tersebut. Terdapat seramai 29, 618 pengundi berdaftar yang terdiri daripada $66.54 \%$ bumiputera Islam $(19,708), 29.93 \%$ bumiputera bukan Islam $(8,865), 3.19 \%(945)$ dan lain-lain $0.34 \%$ (100). Demografik pengundi ini hakikatnya dapat menjelaskan sebab mengapa kemenangan parti BN sebelum ini dalam PRU14 adalah tipis dan dalam PRK Kimanis juga, angka majoriti kemenangan BN juga tidak begitu besar berbanding peratusan keluar mengundi dalam PRU14 yang lalu. Terdapat kemungkinan pengundi-pengundi wujud situasi groupthink dan kesan bandwagon dalam kalangan pengundi yang meyakini bahawa kerajaan Warisan boleh menang dengan mudah dan dengan sebab itu ramai pengundi luar kawasan yang tidak balik mengundi pada 18hb Januari 2020 kerana isu lokal tidak begitu memberi kesan kepada pengundian kelak. Rumusan oleh informan kajian yang ditanya menerusi temuramah bersemuka selepas keputusan diumumkan pada malam penjumlahan undi menggariskan tiga sebab yang boleh dipertanggungjawabkan atas kekalahan Parti Warisan iaitu, 1). isu Pas Sementara Sabah (PSS) yang sukar ditangani dengan betul oleh pihak kerajaan, 2). jentera kempen Parti Warisan yang agak kelam kabut, dan; 3). sebilangan besar pengundi-pengundi Parti Warisan tidak keluar mengundi atas sebab tertentu.
\end{abstract}

Kata kunci: groupthink, kesan bandwagon, petisyen, jentera kempen, isu lokal

\section{Kimanis by-election: Local Issues, Campaign Machinery and the Glory of Barisan Nasional}

\begin{abstract}
The rejection by the Election Court on an appeal by the incumbent of Kimanis parliamentary seat toward the petition to challenge the victory has led to the 2020s Kimanis by election. There were 29 , 618 registered voters consisting of $66.54 \%$ Muslim (19.708), $29.93 \%$ of non-Muslim $(8,865), 3.19 \%$ (945) and others $0.34 \%$. The demographic itself could somewhat explain the reason on why Barisan National won a slim majority in the 14th general election. On contrary, a number of BN's majority for the 2020s Kimanis by election is not very large compared to a number of turnout in the last 14th general election. There was a potential voter which technically linked to the situation of groupthink as well as the bandwagon effect who believes that the Warisan as government of the day could win easily and for that reason many outstation voters who did not go to cast the votes strongly believe that Warisan could win on January 18th, 2020 as the local issue is not going to be a factor which affecting the voters' choice and determination. This study was conducted by having a series of face-to-face interview right after the results were announced. Those grassroots who were asked outline
\end{abstract}


DOI: https://doi.org/10.47405/mjssh.v5i10.496

three major reasons on the defeat, namely, 1). The Pas Sementara Sabah (PSS) seems not properly addressed by Warisan, 2). The Warisan's campaign machinery rather chaotic, and; 3). Some or many of standing voters for Warisan did not turn out for some reason.

Keywords: groupthink, bandwagon effects, petition, campaign machinery, local issues

\section{Pengenalan}

Perbicaraan semula telah didengar di hadapan Hakim Mahkamah Pilihan Raya, Lee Heng Chung yang kemudiannya membatalkan keputusan di kawasan Parlimen tersebut dan memutuskan bahawa kehadiran kertas undi tambahan telah mempengaruhi keputusan undi. Mahkamah Persekutuan sekaligus menolak usaha terakhir Datuk Seri Anifah Aman untuk menyemak semula keputusan dibuat mahkamah sama yang membatalkan kemenangannya di kerusi Parlimen Kimanis pada Pilihan Raya Umum ke-14 (PRU14). Keputusan Mahkamah Persekutuan panel lima hakim diketuai Datuk Mohd Zawawi Salleh telah sebulat suara menolak permohonan Datuk seri Anifah bagi semakan semula keputusan Mahkamah Persekutuan pada 2 Disember 2019 yang secara otomatik membatalkan kemenangannya di Kimanis dalam PRU14 (Bernama, 2020).

Kerusi Parlimen P176 Kimanis dimenangi oleh Datuk Seri Anifah Aman@ Haniff Amman (BNUMNO) dengan majoriti 156 undi bersamaan 11, 942 undi (40.3\%), manakala, Datuk Karim Bujang (Warisan) 11, 786 (39.8\%) diikuti Sdr. Jaafar Ismail (PHRS) 4.4\% bersamaan 1,300 undi dalam PRU14 yang lalu. Namun, kemenangan Datuk Anifah telah dibatalkan menerusi petisyen mahkamah yang difailkan oleh Datuk Karim Bujang pada 18hb Jun 2019 yang dibatalkan oleh Supang Lian, Hakim Mahkamah Pilihanraya pada 19hb November 2019. Namun, pada 18hb Februari 2019, Mahkamah Persekutuan merujuk kembali petisyen pilihan raya Datuk Karim ke Mahkamah Pilihan Raya untuk perbicaraan selepas membenarkan rayuannya untuk membatalkan keputusan Mahkamah Pilihan Raya sebelum itu yang menolak petisyen Karim.

Penamaan Calon pada 4hb Januari 2020 di Dewan Datuk Seri Panglima Dun Banir di Beaufort menyaksikan pertembungan satu lawan satu antara Datuk Karim Bujang (Warisan) dengan Datuk Mohamad Hj. Alamin (Barisan Nasional). Kehadiran ramai ahli parti-parti komponen Pakatan Harapan (PH) dan Barisan Nasional memperlihatkan sokongan yang padu bagi menjayakan kempen Pilihanraya Kecil Kimanis (PRK) P176 Kimanis ini (lihat gambarajah 1).

\section{Rajah 1: Biodata Calon PRK Kimanis}






\section{Kajian Lepas}

Pandangan Syed Arabi dan Rizwanah (2019) terhadap kualiti kempen oleh Barisan Nasional (BN) jelas menerusi rumusan kajian penyelidik berkenaan terhadap maklumbalas akarumbi ke atas mesej kempen $\mathrm{BN}$ sejak $\mathrm{BN}$ menguatkuasakan kaedah kempen dari rumah ke rumah, ceramah kelompok dan acara berjumpa dengan masyarakat. Penggunaan maklumat yang realistik bagi menggambarkan ketrampilan BN sebagai kerajaan suatu ketika dahulu memberikan panduan kepada pengundi-pengundi untuk menilai jasa dan sumbangan BN kepada Parlimen Kimanis. Sungguhpun begitu, adalah tidak wajar bagi Parti Warisan yang baharu menjadi kerajaan selama 20 bulan untuk dibandingkan secara material dengan $\mathrm{BN}$ yang berkuasa lebih 60 tahun di peringkat persekutuan dan negeri.

Kewujudan UMNO-Barisan Nasional (BN) di Sabah bermula 9 Mac 1991 (Hamdan \& Syahrin, 2017) menandakan permulaan dominasi parti berkenaan menerusi pilihanraya negeri Sabah pada 1994. Sejarah parti UMNO yang panjang sejak itu telah memberi impak kepada penyusunan jentera kempen parti secara berstruktur. Ini yang demikian kerana, BN meletakkan jentera parti sebagai aset yang penting dan berguna dalam memastikan maklumat serta mesej kempen disampaikan kepada akar umbi pada tahap optimum. Kehadiran parti-parti komponen BN dilihat sebagai rencah yang masih relevan untuk meraih pengundi pelbagai etnik dan agama di negara ini (Muhamad, 2018). Oleh itu, pengalaman yang luas dalam gerakerja kempen oleh BN agak berbeza dengan Pakatan Harapan amnya dan Warisan khususnya dalam PRK Kimanis.

Dalam hal berkaitan kempen di atas talian pula, Rosyidah (2015) menjelaskan dalam kajian beliau bahawa, internet telah memberikan kemudahan kepada parti-parti politik di Malaysia untuk menjalankan kempen secara efisien tanpa mengira masa dan tempat. Bahan kempen boleh diakses sepanjang masa, diolah dengan cara yang pelbagai dan disasarkan kepada pengundi-pengundi baru serta pengundi atas pagar. Situasi ini berlaku dan menjadi praktis dalam kalangan akarumbi bagi mereka berkongsi bahan kempen sesama rakan dan sanak saudara di Kimanis.

Dalam konteks politik kenegerian pula, Mohammad Agus (1999) bahawa politik negeri Sabah hari ini kekal relevan mengamalkan politik centre-state. Ini turut menjelaskan sebab mengapa slogan Sabah for Sabahan dan Sabah sebagai Wilayah menerusi Perjanjian Malaysia 1963 (MA63) masih mendapat sokongan masyarakat setempat masih menjadi sebab mengapa politik di negeri Sabah masih mengekalkan aspirasi etnik dan lokaliti untuk meraih undi penduduk tempatan (Loh, 2009).

Dalam masa yang sama, kebijaksanaan BN dalam memanipulasikan isu PSS memberi kesan kepada pemikiran dan corak pemilihan parti. Sama ada undi berkenaan bersifat tulen untuk menyokong BN atau satu petunjuk protes kepada Warisan, masih boleh dipersoalkan. Ini yang demikian kerana, dapatan kajian Faisal (2015) mengesahkan bahawa sejak beberapa PRU, kumpulan minoriti penduduk di Sabah khususnya di luar bandar masih bergantung kepada naungan parti yang dominan yang terbukti pernah dan boleh memberikan bantuan berterusan dalam apa cara sekalipun demi kelangsungan hidup mereka.

Dalam konteks isu yang digembar-gemburkan dalam kempen pilihanraya, Mohamad Nawab (2017) menjelaskan bahawa, perubahan sentimen popular mengikut isu semasa boleh meningkatkan kesedaran dalam kalangan pengundi untuk "swing" memilih mana-mana parti politik yang berupaya memberikan keyakinan terhadap masa depan dan kepentingan mereka. Oleh itu, persoalan yang timbul, adakah keputusan PRK Kimanis ini sudah diramal di mana BN akan menang? Secara lateral mungkin tidak kerana Parti Warisan dilihat masih mampu mengekalkan sokongan akarumbi di Parlimen Kimanis pada tahap optimum. Sungguhpun begitu, secara teknikal, BN sudah diramal menang seawal minggu pertama kempen PRK Kimanis ini. Keupayaan BN menyusun dan menggerakkan jentera selain menghimpunkan nama-nama besar mantan pemimpin $\mathrm{BN}$, pucuk pimpinan UMNO malah juga penglibatan Parti Islam Semalaysia (PAS) menjadi prasyarat kepada kemenangan BN di lokasi kempen dan di Pusat-Pusat Daerah Mengundi (PDM). Dengan kata lain, jentera kempen adalah nadi kepada gerakerja dan halatuju satu-satu pelan kempen sesebuah parti politik (Syahruddin, 2010). Justeru, keupayaan sesebuah parti politik dalam satu-satu jangkawaktu kempen pilihanraya ditentukan oleh 
DOI: https://doi.org/10.47405/mjssh.v5i10.496

kelancaran jentera parti baik dari segi pelaksanaan program-program kempen, mahu pun dari segi usaha untuk menjawab mana-mana isu setempat yang ditimbulkan oleh parti lawan.

\section{Konsep Groupthink dan Kesan Bandwagon}

Groupthink adalah istilah yang digunakan buat pertama kali oleh penteori psikosial, Irving L. Janis pada tahun 1972 (Hart, 1991; Hart, 1998) bagi menjelaskan fenomena psikologi di mana setiap individu mempunyai inisiatif dan daya usaha untuk mencapai persepakatan dalam satu kumpulan. Dalam banyak kes, seseorang dalam kumpulan mempunyai kesanggupan untuk mengetepikan kepercayaan peribadi mereka sendiri dan membuka fikiran serta hati mereka untuk mengamalkan pendapat kumpulan. Sekiranya terdapat individu tertentu dalam kumpulan berkenaan yang mempunyai pendapat yang berbeza, individu berkenaan cenderung untuk mendiamkan diri dan mengutamakan keharmonian berbanding pertelagahan idea atau pandangan agar wujud keseragaman pendapat dalam kumpulan tersebut.

Dalam konteks kempen pilihanraya dan pilihan dalam pengundian, konsep groupthink menyebabkan seseorang mempersoalkan tindakan dirinya yang berlainan atau sama dengan ahli kumpulan lain. Pertimbangan secara senyap-senyap dilakukan tetapi usaha untuk mendapatkan pandangan umum dilakukan secara terbuka. Hasilnya, akan wujud pilihan yang dominan dalam keputusan pengundian dalam satu-satu kawasan akarumbi sesebuah parti. Keadaan ini memberi kesan langsung kepada keterlihatan jumlah sokongan terhadap satu-satu parti politik yang menyebabkan satu-satu kawasan pilihanraya dikategorikan sebagai hitam, kelabu atau putih oleh sesebuah parti politik.

Groupthink juga sebenarnya berkait rapat dengan konsep bandwagon di mana, persepakatan dalam kalangan akarumbi dalam satu-satu pilihanraya diletakkan kepada hanya dua iaitu, calon yang diketengahkan atau parti yang bertanding. Konsep bandwagon yang dikaitkan dengan perkongsian dan pemprosesan makluman (Mehrabian, 1998) dalam kalangan ahli-ahli sebuah kumpulan, berupaya mendorong terbentuknya kesepakatan dalam bertindak dan membuat keputusan terhadap sesuatu. Acapkali, kesan bandwagon memberikan maklumat berguna kepada penganalisis politik dan parti-parti politik yang bertanding tentang corak sokongan pengundi di satu-satu kawasan pilihanraya. Bagaimana pula dengan pendirian dan halatuju pemimpin serta parti Warisan sebagai parti yang berteraskan anak watan Sabah? Adakah pandangan Farish (2016) tentang “....a growing sense of local identity politics is evident..." benar-benar berlaku dalam kalangan rakyat Sabah yang boleh dimanfaatkan oleh Parti Warisan untuk mewujudkan identiti politik negeri Sabah oleh orang Sabah? Adakah slogan 'Sabah for Sabahan' boleh menjadi jaminan bagi kempen-kempen politik parti Warisan pada masa akan datang untuk mendapatkan sokongan menerusi kesan bandwagon?

\section{Metodologi}

Pasukan penyelidik menggunakan kaedah temuramah bersemuka dan pemerhatian aktif bagi mendekati pengundi dalam kumpulan kecil (restoran, rumah kediaman, balairaya, masjid dan stesen keretapi) masing-masing di semua Pusat Daerah Mengundi (PDM) di kedua-dua kawasan Dewan Undangan Negeri (DUN) N23 Bongawan dan N24 Membakut. Penyelidik dan pembantu penyelidik telah membuat temubual dan tinjauan di PDM, menemui pemimpin-pemimpin parti politik yang bertanding, menghadiri acara ceramah kelompok dan membuat pemerhatian cara kedua-dua kempen menggerakkan jentera sebelum tempoh rasmi kempen bermula iaitu dari 25hb Disember 2019 sehingga 19hb Januari 2020.

Penyelidik membuat perancangan kerja lapangan menggunakan pendekatan kualitatif melalui kaedah etnografi politik (Auyero, 2012; Priyam, 2016; Md. Rubel, 2017) bagi mengenalpasti fenomena pilihanraya kecil ini seawal 25hb Disember 2019 dengan berhubung terus kepada beberapa informan yang juga merupakan pemimpin parti, pekerja-pekerja parti dan pemerhati politik di kedua-dua Dewan Undangan Negeri (DUN) N23 Bongawan dan N24 Membakut di samping membuat tinjauan di lokasi acara kempen. Penyelidik menyenaraikan sumber-sumber maklumat dalam kalangan akarumbi dan 
pekerja serta pemimpin parti UMNO-BN dan Warisan untuk mengetahui enam perkara berikut iaitu, 1) persiapan parti dalam menghadapi PRK Kimanis, 2) maklumat awal tentang keyakinan parti-parti yang bertanding terhadap potensi menang, 3) jadual acara yang mengisi kempen sepanjang dua minggu, 4) maklumat tentang perancangan strategi dan taktik kempen, 5) pemerhatian terhadap gerakerja lazim dalam persiapan dan pelaksanaan gerakerja kempen, dan; 6) menyertai acara-acara kempen seperti ceramah kelompok, kerja-kerja persiapan Pusat Daerah Mengundi (PDM) dan seumpamanya.

\section{Dapatan Kajian}

Secara teknikal. petunjuk kemenangan UMNO-BN dalam PRK Kimanis dipaparkan lebih awal menerusi gerakerja kemas dan berterusan oleh pekerja-pekerja parti sejak sebelum hari penamaan calon lagi. Pemimpin-pemimpin BN dari Kuala Lumpur pula memberikan sokongan moral yang siginifikan melalui kehadiran mereka dalam acara-acara seperti Ceramah Perdana Kenduri Rakyat pada $1 \mathrm{hb}$ Januari 2020 di Dataran Sedco, Pimping iaitu sebuah kampung dalam kawasan Dewan Undangan Negeri (DUN) N24 Membakut.

Justeru, kehadiran parti-parti komponen BN dan Pakatan Harapan dalam PRK Kimanis menyaksikan kemeriahan kempen di kawasan ini. Selain dari itu, pembukaan Command Centre di Kimanis Centro juga memberikan impak dari segi imej dan reputasi parti-parti yang bertanding dan kebetulan keduadua parti membuka pejabat pusat kempen masing-masing di blok rumah kedai yang sama di sana.

Namun, berbanding jentera BN, jentera kempen Warisan tidak kemas dari segi arahan dan gerakerja di Pusat Daerah Mengundi (PDM) Membakut dan Bongawan. Kelewatan gerakerja dimulakan berpunca dari kesefahaman dalam menentukan bentuk dan jenis tugasan kempen antara jentera kempen PRK Kimanis dengan cawangan-cawangan Warisan dari seluruh negeri terutama dari sebelah Pantai Timur Sabah dan Kota Kinabalu (Jentera Parlimen Sepanggar).

Pertindihan arahan dan kecelaruan mesej yang sepatutnya disampaikan kepada akarumbi adalah punca mengapa pengundi-pengundi berasa kurang diberikan maklumat yang tepat tentang jadual acara-acara yang dirancang sebagai pengisian kempen kali ini. Jentera Kempen Warisan Kimanis diketuai oleh Datuk Jaujan Sambakong yang juga merupakan Pembantu Menteri. Datuk Jaujan tidak mengetahui sepenuhnya selok-belok dan adat resam masyarakat Melayu-Brunei yang mendominasi Kimanis.

Sepatutnya Datuk Dr. Yusof Yakub, Menteri Pelajaran dan Inovasi Sabah, merangkap Ketua Penerangan Warisan Negeri Sabah dilantik sebagai Pengerusi Jentera Kempen PRK Kimanis atau mungkin Dr. Daud Hj. Yusof Aahli Dewan Undangan Negeri (ADUN) N23 Kimanis kerana kedua-dua individu ini amat arif dengan selok-belok Kimanis dan kawasan persekitarannya lebih-lebih lagi mereka mempunyai sanak saudara yang ramai di kawasan tersebut.

Dari segi kandungan mesej kempen yang berpusat kepada isu semasa, topik berkaitan PSS yang hakikatnya adalah satu mekanisme dokumentasi rasmi melalui pendaftaran individu bukan warganegara yang sudah sedia berada di negeri Sabah tetapi individu berkenaan memiliki mana-mana satu daripada tiga jenis dokumen iaitu Kad Banci dalam Program Pemutihan dalam tahun 1990an, Kad Burung-Burung dan juga IMM13 (UNHCR). PSS yang bakal diperkenalkan di negeri ini akan menggabungkan semua dokumen berkenaan di dalam satu konseppendaftaran sementara yang mempunyai tempoh sahlaku selama tiga tahun.

Walau bagaimanapun, isu PSS tidak dijawab secara betul terutama oleh parti-parti sekutu Warisan seperti UPKO di mana sepatutnya UPKO mempunyai kapasiti yang sesuai dalam memberikan kefahaman kepada etnik Kadazan-Dusun dalam hal berkaitan dengan Pas Sementara Sabah (PSS). Sebaliknya, UPKO cenderung untuk membuat kenyataan menentang PAS yang dikatakan ekstrimis dan mempunyai agenda tertentu dalam kempen di Kimanis.

Sepatutnya organisasi jentera kempen Warisan menyediakan saluran komunikasi dan medium yang pelbagai dalam memberikan penerangan tentang isu PSS kepada penduduk setempat tanpa 
mengharapkan Timbalan Menteri Dalam Negeri sahaja memberikan pencerahan dalam setiap ceramah kelompok yang beliau hadiri. Berbeza dengan BN, kempen di internet dimanfaatkan sebaik mungkin sepanjang masa dan ia seolah dirancang dengan sengaja untuk objektif-objektif kempen yang khusus seperti penyebaran mesej tekstual dan keratan akhbar menerusi laman facebook untuk menimbulkan persepsi dalam kalangan penduduk selain penggunaan poster digital untuk memaparkan mesej satira yang agak sinis kepada Parti Warisan dengan harapan, pengundi di Parlimen Kimanis hilang kepercayaan kepada kepimpinan kerajaan negeri dan persekutuan.

Dari sudut penggunaan media sosial sebagai platform kempen, parti $\mathrm{BN}$ telah belajar dari parti pembangkang semasa era pemerintahan mereka. Kelebihan internet sebagai saluran yang anjal dari segi masa dan kandungan mesej membolehkan BN mengupas isu PSS dari perspektif yang negatif sehingga menimbulkan persepsi dan kebencian terhadap Parti Warisan dalam kalangan pengundi-pengundi di Parlimen Kimanis. Penggunaan satira politik atau lampoon secara meluas serba sedikit memberikan impak kepada cara akarumbi di Parlimen Kimanis berfikir dan membuat keputusan. Perkongsian meluas berkaitan isu semasa dalam media sosial telah mendorong wujudnya kesan bandwagon dalam kalangan akarumbi bagi membuat pilihan calon.

Kesan 'bandwagon' juga memberikan perspektif yang dijangka bagi pengundi-pengundi yang rata-rata adalah saling bersaudara di kawasan ini. Kawasan Kimanis, Bongawan dan Membakut secara umum pula didiami oleh penduduk-penduduk yang lebih $60 \%$ beragama Islam dan berketurunan MelayuBrunei mengatasi komposisi kaum dan agama lain. Isu semasa yang berkaitan dengan ancaman kepada keselamatan, kesejahteraan dan keharmonian dalam kalangan masyarakat tersebut adalah keutamaan dalam hal ehwal sosio ekonomi dan politik mereka termasuklah isu PSS.

Dari aspek semangat dan sokongan pengundi pula, gambaran awal tentang aura pengundian di lapangan menunjukkan sambutan kurang memberangsangkan dalam kalangan pengundi di Parlimen Kimanis terutama di Pusat-Pusat Daerah Mengundi (PDM) yang terletak di kawasan agak jauh dari pekan Bongawan dan pekan Membakut. Bilangan pengundi yang keluar agak kurang pada sekitar jam 10 pagi di beberapa Pusat Mengundi utama seperti di Sek. Keb. Kimanis sebagai Pusat Mengundi bagi calon Parti Warisan begitu juga di Sek.Keb Binsulok yang dilihat sebagai 'kawasan hitam dan kelabu' kepada pihak Parti Warisan dan berpotensi menentukan pemenang kepada BN seperti dalam PRU14 dan PRU13 yang lalu (lihat gambarajah 2).

Rajah 2: Peta Lokasi Pusat Daerah Mengundi (PDM) di P176 Kimanis

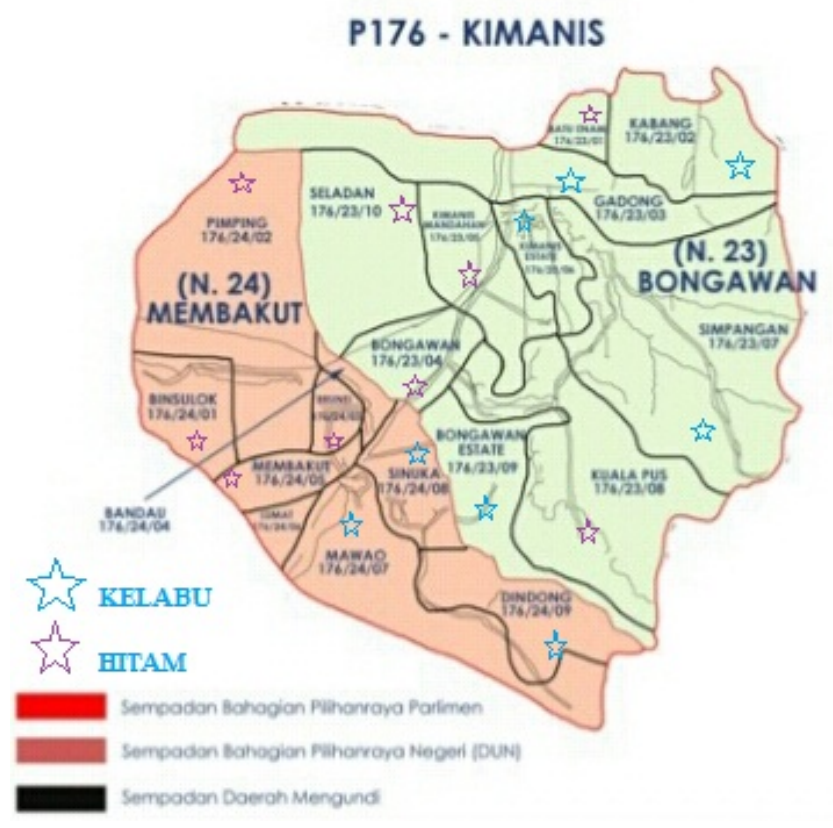


DOI: https://doi.org/10.47405/mjssh.v5i10.496

Jumlah pengundi yang keluar mengundi agak sedikit iaitu 23,708 orang (79.92\%) berbanding PRU14 seramai $25,519(86.2 \%)$. Banyak sebab yang boleh dikaitkan dengan pengurangan jumlah pengundi kali ini antaranya termasuklah, rasa selesa pengundi terhadap keadaan sedia ada selepas PRU14, pengundi di luar kawasan yang tidak dapat balik atau memilih untuk tidak balik ke Parlimen Kimanis dan seumpamanya mungkin atas sebab mereka yakin bahawa sebagai parti kerajaan, Warisan menang dalam PRK Kimanis ini.

Daripada 29, 664 jumlah pengundi berdaftar di Parlimen ini, 9 orang adalah pengundi awal dan seorang pengundi tidak hadir. Pihak Suruhanjaya Pilihanraya Malaysia (SPR) menyediakan 69 saluran mengundi di 20 Pusat Mengundi dengan dibantu seramai 653 orang petugas. Proses pengundian berjalan lancar seperti yang dijadualkan oleh Suruhanjaya Pilihanraya Malaysia (SPR) walaupun terdapat insiden provokasi dalam ceramah-ceramah kempen antara kedua-dua parti bertanding selain daripada perhimpunan membantah PSS oleh Parti Bersatu Sabah (PBS) di stesen keretapi pekan Membakut.

Menurut daftar pengundi SPR, pengundi-pengundi di N23 Bongawan adalah seramai 16, 272 orang (masing-masing 8, 096 pengundi lelaki $49.75 \%$ dan 8, 177 pengundi wanita $50.25 \%$ ), manakala, N24 Membakut pula seramai 13, 382 orang (iaitu seramai 6,704 pengundi lelaki, 50.06\% dan seramai 6,687 pengundi wanita bersamaan 49.94\%) termasuk 9 orang pengundi awal iaitu anggota polis dan pasangan. Pengundi yang berumur antara 30 ke 39 tahun adalah yang paling ramai di kedua-dua DUN N23 dan N24 iaitu masing-masing 4,325 orang (26.58\%) di Bongawan dan seramai 3,567 (26.64\%) di Membakut (lihat gambarajah 3).

Rajah 3: Maklumat pemilih di parlimen P176 Kimanis yang dikemaskini oleh Suruhanjaya Pilihanraya Malaysia

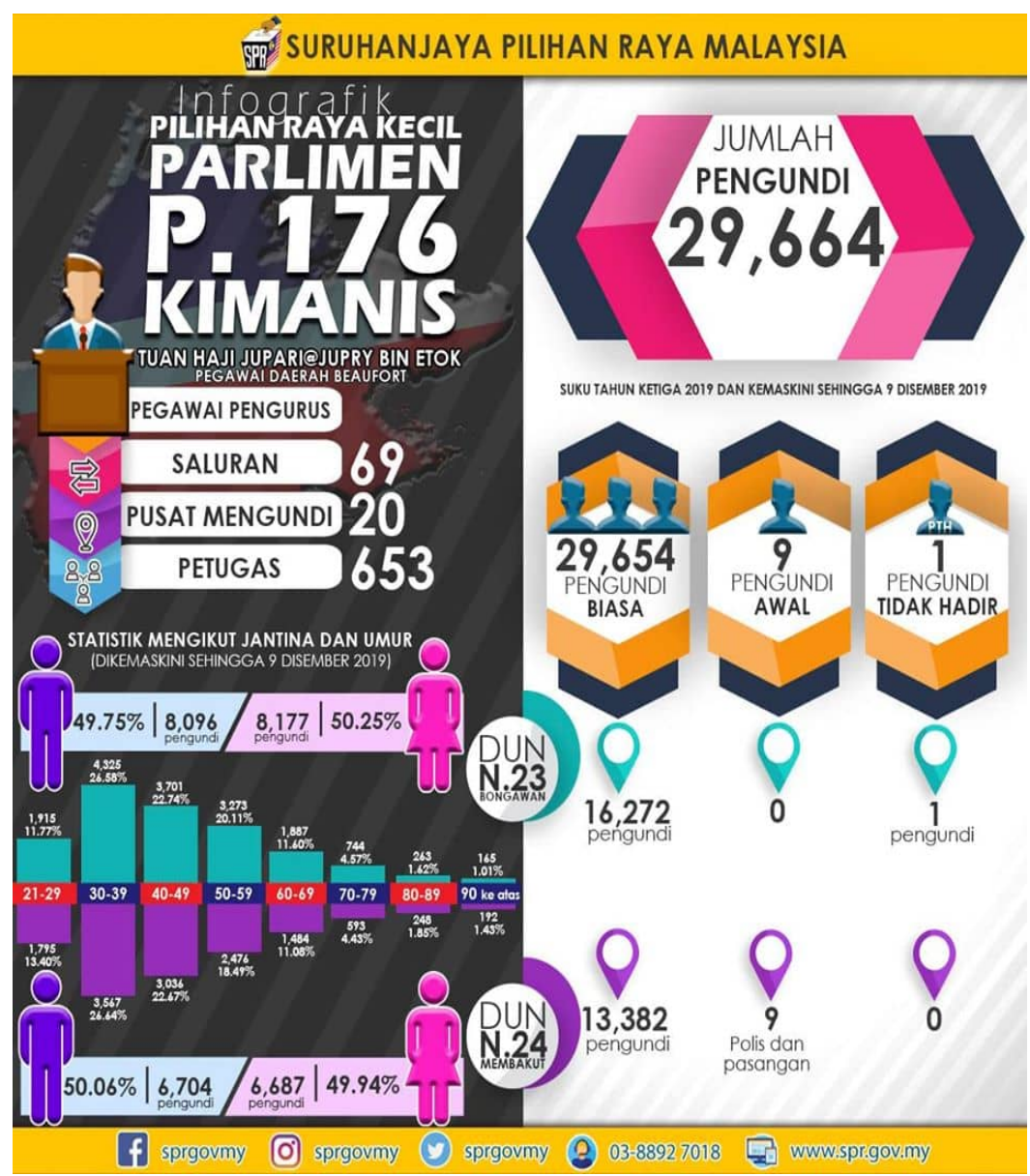


DOI: https://doi.org/10.47405/mjssh.v5i10.496

Keputusan PRK Kimanis menyaksikan Datuk Mohamad Hj. Alamin memenangi kerusi Parlimen dengan majoriti sebanyak 2029 undi mengatasi Datuk Karim Bujang (lihat gambarajah 4). Sungguhpun kemenangan ke atas BN adalah satu petanda bahawa P176 Kimanis masih kekal sebagai kubu kuat $\mathrm{BN}$, namun, pertandingan dua penjuru agak berbeza dengan pertembungan tiga penjuru ketika PRU14 yang lalu di mana Calon Parti Harapan Rakyat Sabah (PHRS) Sdr. Jaafar Ismail memperoleh undi sebanyak 1340. Justeru, kali ini undi majoriti yang diperoleh BN kemungkinan datang dari pengundi-pengundi PHRS pada ketika itu. Pengundi atas pagar yang tidak pro-BN dan Warisan pada ketika itu mungkin beralih arah kepada BN atas sebab prestasi serta keupayaan Warisan dalam menangani pembangunan negeri dalam tempoh kira-kira 20 bulan yang lepas. Keputusan PRK P176 Kimanis ini dianggap sebagai petanda bahawa rakyat khususnya warga Kimanis masih menaruh harapan terhadap Warisan sebagai parti tempatan di negeri ini untuk memperjuangkan hak dan nasib rakyat negeri ini terutama dalam soal hak orang asal di negeri Sabah.

Rajah 4: Keputusan Penuh PRK P176 Kimanis (Semua Saluran Mengundi)

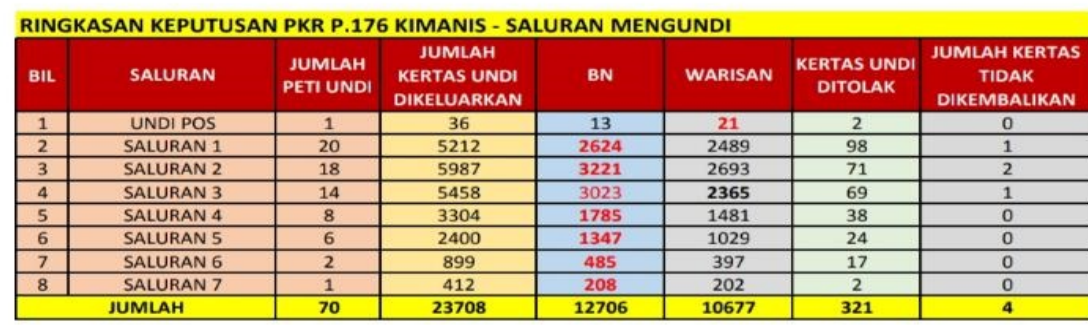

KEPUTUSAN
\begin{tabular}{|l|c|}
\hline JUMLAH KERTAS UNDI DIKELUARKAN & 23708 \\
\hline BARISAN NASIONAL & 12706 \\
\hline WARISAN & 10677 \\
\hline JUMLAH UNDI ROSAK & 321 \\
\hline JULAH KERTAS TIDAK DIKEMBALIKAN & 4 \\
\hline MAJORTI & 2029 \\
\hline
\end{tabular}



KEPUTUSAN

\begin{tabular}{|l|c|}
\hline JUMLAH KERTAS UNDI DIKELUARKAN & 23708 \\
\hline BARISAN NASIONAL & 12706 \\
\hline WARISAN & 10677 \\
\hline JUMLAH UNDI ROSAK & 321 \\
\hline JULAH KERTAS TIDAK DIKEMBALIKAN & 4 \\
\hline MAJORTI & 2029 \\
\hline
\end{tabular}

\section{Kesimpulan}

Secara keseluruhan, PRK Kimanis menyaksikan pertembungan dua individu yang lahir dalam budaya politik yang mempunyai persekitaran serta pengikut yang sama. Kedua-dua calon saling mengetahui strategi dan taktik yang digunakan oleh lawan masing-masing dan dari segi maklumat kempen, keduadua calon akur bahawa maklumat seperti latarbelakang penyokong, kawasan yang dikuasai, keberkesanan mesej kempen dan penggunaan media sosial begitu berpengaruh. Ini yang demikian 
DOI: https://doi.org/10.47405/mjssh.v5i10.496

kerana, pengundi di Parlimen P176 Kimanis telah melalui banyak PRK dan PRN sebelum ini. Pengundi-pengundi di saluran 1, 2, 3 dan 4 telah mempunyai keputusan tersendiri tentang calon yang mereka mahu mewakili mereka secara tradisi. Adakah generasi pengundi di keempat-empat saluran ini mempunyai pendirian masing-masing yang bersifat solid kepada BN sejak PRU 14 yang lalu? Begitulah juga dengan pengundi muda, pengundi baru dan pengundi atas pagar, kehendak pengundipengundi ini digembleng dengan jitu melalui perbincangan sesama mereka baik di laman maya mahu pun secara bersemuka. Sungguhpun begitu, elemen nyata yang begitu menonjol yang boleh dikaitkan dengan kelancaran kempen adalah rekabentuk dan cara jentera dioperasikan sepanjang tempoh kempen berjalan selama dua minggu.

\section{Rujukan}

Auyero, J. (2012). Poor people's lives and politics: The things a political ethnographer knows (and doesn't know) after 15 years of fieldwork. New Perspectives on Turkey, 46, 95 - 127

Bernama (2020, 3 Januari 2020). Anifah gagal usaha akhir batal keputusan petisyen pilihanraya Kimanis. Sinar Harian. Dipetik daripada https://www.sinarharian.com.my/article/64454/BERITA/Mahkamah/Anifah-gagal-usaha-akhirbatal-keputusan-petisyen-pilihan-raya-Kimanis

Brady, H. E, Johnston, R. \& Sides, R. (2006) The Study of Political Campaigns. In Brady, H.E. and Johnston, R (eds) Capturing Campaign Effects. Ann Arbor, MI: University of Michigan Press.

Faisal S. Hazis. (2015). Patronage, Power And Prowess: Barisan Nasional'S Equilibrium Dominance In East Malaysia. Kajian Malaysia, 33(2), 1-24

Farish A. Noor. (2016). A New Player in Sabah Politics. RSIS Commentary. 62 Dipetik Daripada: https://www.rsis.edu.sg/wp-content/uploads/2016/10/CO16262.pdf. Pada: 22 Januari 2020

Hamdan Aziz \& Syahrin Said. (2017). The United Malays National Organisation (UMNO) in Sabah, East Malaysia: An Overview 1990-1994. International Journal of Academic Research in Business and Social Sciences, 7(12), 565-575

Hart, P. (1998). "Preventing groupthink revisited: evaluating and reforming groups in government". Organizational Behavior and Human Decision Processes, 73(2-3), 306-326.

Hart, P. (1991). Irving L. Janis' Victims of Group think. Political Psychology, 12(2), 247-278

Loh, K.W. (2009). New and Old Politics in Malaysia: State and Society in Transition. Kuala Lumpur: SIRD.

Md. Rubel Mia. (2017). An Ethnographic Account on the Local Politics inRural Bangladesh: A Case from Bogra District. Journal Of Humanities And Social Science (IOSR-JHSS), 22(12), 61-79

Mehrabian, A. (1998). Effects of Poll Reports on Voter Preferences" Journal of Applied Social Psychology, 28(23), 2119-2130.

Mohamad Nawab Mohamad Osman. (2017). A Transitioning Sabah In A Changing Malaysia, Kajian Malaysia, 35(1), 23-40

Mohammad Agus Yusoff (1999). The Politics of Centre-State Conflict: Sabah Experience Under the ruling Sabah Alliance (1963 - 1976). Jebat, 26, 1-25

Priyam, M. (2016). Political ethnography as a method for understanding urban politics and elections in India. Studies in Indian Politics, 4. 119 - 127

Muhamad Nazri. (2018), The 14th General Election, the Fall of Barisan Nasional, and Political Development in Malaysia, 1957-2018. Journal of Current Southeast Asian Affairs, 37(3), 139171.

Rosyidah Muhamad. (2015). Online Opposition and Elections in Malaysia. Asian Social Science; 11(10), 281-291

Syahruddin Ag. Ahmad (2010). Kempen dan Pembujukan. Kota Kinabalu, Sabah: Penerbit UMS

Syed Arabi Idid \& Rizwanah Souket. (2019). Barisan Nasional's GE14 campaign materials: A reversed third-person effect. Journal of Media and Communication Research, 11(2),1-19

Tony Paridi Bagang \& Asri Salleh (2019). Krisis Politik Sabah Pasca Pilihanraya Umum Ke-14. International Conference On Politics And International Studies 2018 pada 30 - 31 Oktober 2018 di UMS. 1-19 